\title{
Søren Kierkegaard: por uma filosofia da existência
}

\section{[Søren Kierkegaard: in favor of na existence phylosophy]}

\author{
André Luiz Holanda de Oliveira*
}

\begin{abstract}
Resumo
A filosofia de Søren Kierkegaard é acentuadamente marcada pela concretude da existência. Esta jamais é vista como um conceito a ser incluído num sistema, emergindo, em seus elementos fundamentais, do âmbito da interioridade, onde se encontra a paixão ideal que está a serviço de um valor absoluto. É, portanto, na existência, que Kierkegaard identifica o locus irrenunciável da verdadeira reflexão filosófica. Fora desta dimensão o homem não conquista sua autenticidade, pois é só aqui que o homem se compreende como dependente de sua relação com o Absoluto, tomando consciência do sentido último de sua vida. A existência humana enquanto concretude e liberdade; resiste à dissolução do indivíduo e é, acima e tudo, existência do indivíduo singular perante o Absoluto na dimensão da paradoxalidade da fé.
\end{abstract}

Palavras-chave: Kierkegaard; Existência; Subjetividade, Fé.

\begin{abstract}
The philosophy of Kierkegaard is sharply marked by concreteness of existence. This is never seen as a concept to be included in a system, emerging, in its fundamental elements, from the scope of interiority, where the ideal passion is at the service of an absolute value. It is therefore in existence, that Kierkegaard identifies the indispensable locus of true philosophical reflection. Out of this dimension man does not conquer its authenticity, because it is only here that man is understood as dependent on their relationship with the Absolute, becoming aware of the ultimate meaning of his life. Human existence as concrete and freedom; resists dissolution of the individual and is, above and all, existence of singular individual in front of the Absolute in the paradoxical dimension of faith.
\end{abstract} Key-words: Kierkegaard; Existence; Subjectivity; Faith

\section{Introdução}

O pensamento inquietante de Kierkegaard, acessível através dos seus escritos, representou gradativamente para a Filosofia o elemento definidor de toda uma postura que, desde então, veio a

* Licenciado, Mestre e Doutor em Filosofia (UFPE). Professor de Filosofia na Universidade Católica de Pernambuco. 
identificar uma preocupação com a existência humana; por isso não há como minimizar o papel do pensamento kierkegaardiano na estruturação da Filosofia contemporânea.

Precisamos destacar que os escritos de Kierkegaard refletem a conflituosidade dialética da sua própria biografia, ou seja, ao lidarmos com Kierkegaard teremos de esbarrar com aspectos que revelam a inquietude daquilo que foi a sua vida pessoal: a educação extremamente rígida recebida durante a infância, a relação conflituosa e mal-resolvida com o seu pai, a excessiva melancolia e a concepção austera quanto ao sofrimento individual que o acompanharam durante toda a sua vida, as peculiaridades do seu noivado e o seu rompimento traumático sem um motivo realmente convincente, a incapacidade dele se desvincular da sombra permanente de Regine Olsen a partir do rompimento do seu noivado, a sua concepção exageradamente radical do que seria o cristianismo autêntico, a sua indisposição com a Igreja oficial e com os seus representantes, a desgastante briga com $O$ Corsário que resultou na sua ridicularização pública, a sua enfermidade fatal fruto de um colapso.

Uma das razões para explicar o caráter inquietante, polêmico e provocativo (além de se apresentar às vezes bastante hermético) da obra kierkegaardiana é que, muito daquilo que Kierkegaard escreveu deu-se em relação aos próprios acontecimentos de sua vida. Os seus escritos refletem as suas inquietações e dramas existenciais, pois para ele não era possível conceber um filosofar dissociado do existir concreto, ou seja, um filosofar teórico e distante da vida. A existência não é vista por ele como um conceito a ser incluído num sistema de Filosofia ou de Teologia. $\mathrm{O}$ existir não se dá na impessoalidade ou na abstração, pois ele não é mera possibilidade teórica sem efetivação.

\section{Panorama da vida de Kierkegaard}

O dinamarquês Søren Aabye Kierkegaard nasceu em Copenhague, em 5 de Maio de 1813. Ele foi o sétimo e último filho de Michael Pedersen Kierkegaard e Anne Sørensdatter Lund $^{1}$ Michael, em 1794, casou-se com Kierstine Nielsdatter 1 “O nome Kierkegaard era originalmente 'Kirkegaard' e provinha de duas
170 • Universidade Católica dePERnAmbuco 
Royen (1757-1796), que veio a falecer em 23 de Março de 1796 sem gerar filhos. Após a morte da primeira esposa, Michael casouse em 26 de Abril de 1797 com Anne Lund, que era empregada doméstica em sua residência e que estava grávida ainda antes de se casar com Michael. Anne gerou sete filhos, sendo Søren Kierkegaard o último deles. Quando ele nasceu, seu pai tinha 56 anos e sua mãe 45, esta é a razão de Kierkegaard referir-se a si mesmo como um filho da velhice. Um a um os filhos foram morrendo, restando, quando Michael faleceu, apenas Peter Christian (1805-1888) e Kierkegaard. Este achava que a morte de seus cinco irmãos, bem como a riqueza da família, eram um sinal de vingança divina, e que ele e o seu último irmão haveriam de morrer antes do seu pai. ${ }^{2}$

Tendo sido educado num ambiente onde predominava um rigoroso pietismo, Kierkegaard teve uma personalidade profundamente marcada pela religião. A infância de Kierkegaard foi marcada pela melancolia, senso de culpa, ansiedade, severidade e pietismo religioso do seu pai, a quem ele amava muito. Em seus Diários e Papéis, ${ }^{3}$ ele escreveu acerca de sua infância austera e de

herdades, situadas próximas do templo de Saedding, que o bisavô de Kierkegaard (Christen Jespersen, 1673-1749) havia recebido ao casar-se. Para distinguir o seu sobrenome dessa palavra, que também significa 'cemitério', quando já em Copenhague, o pai de Kierkegaard acrescentou um 'e' à primeira sílaba, passando a chamar-se Kierkegaard, nome que o último dos seus filhos haveria de tornar universalmente conhecido". Cf. JOLIVÉT, Régis. As Doutrinas Existencialistas. Porto: Livraria Tavares Martins, 1953, p.197.

2 GOUVÊA, Ricardo. Paixão Pelo paradoxo: Uma introdução a Kierkegaard. São Paulo: Novo Século, 2000, p.25-8.

3 Os Diários e Papéis de Kierkegaard (1834-53), foram publicados postumamente. Sфren Kierkegaards Papirer. P.A. HEIBERG (ed). Copenhagen: Gyldendalske Boghandel Nordisk Forlag, 1909-48. No inglês são conhecidos com o título Kierkegaard's Journals and Papers. Neste artigo, salvo outra indicação, seguiremos a seleção e tradução dos Diários e Papíes feita por Ernani REICHMANN em: Textos Selecionados de S. Kierkegaard. REICHMANN, Ernani(org). Curitiba: UFPR, 1978. A classificação dos Papirer feita por REICHMANN está de acordo com a divisão tríplice dos diários e papéis e deve ser compreendida como segue: $\mathrm{O}$ algarismo romano indica o volume, o arábico indica o número de entrada. Os Papirer são divididos nas seções A, B e C. O grupo designado por A refere-se ao diários e notas pessoais, o grupo B são esboços e notas relacionados com a autoria de Kierkegaard em artigos e obras, enquanto o grupo $\mathrm{C}$ contém notas relacionadas com os estudos e leituras de Kierkegaard, incluindo textos dele mesmo e trechos copiados de outros autores. 
como cresceu vivenciando crises interiores:

Minha desgraça, humanamente falando, consiste em que tive uma educação cristã demasiadamente severa. Desde a infância, vivi sob o domínio de uma melancolia originária. Se tivesse sido educado de uma maneira normal, é certo que não me teria tornado tão melancólico: durante muito tempo tudo fiz para me libertar desta melancolia, que quase me impediu de ser homem. Fiz o impossível porque ou a destruía ou ela me destruiria. ${ }^{4}$

A religiosidade tornou-se para ele uma espécie de habitat natural, gerando em Kierkegaard uma profunda melancolia - fruto de uma vida pautada por severas exigências e advertências quanto ao pecado:

Franzino, raquítico e fraco para poder valer como um homem completo, quando comparado com outros, no ponto de vista das condições físicas que me foram negadas, melancólico, submetido ao sofrimento interior, profundamente ferido de muitas maneiras no íntimo da alma, a mim só uma coisa me foi concedida: uma inteligência eminente, com certeza para que eu não ficasse inteiramente desarmado. ${ }^{5}$

Essa educação marcada pela teologia cristológica do sofrimento, de viés acentuadamente pietista, se fez notar em sua reflexão filosófico-religiosa, influenciando notadamente a cosmovisão kierkegaardiana, conforme ele mesmo afirmou, embora indiretamente:

Havia uma vez um homem que, na infância, tinha sido estritamente educado na religião cristã. Nunca tinha ouvido falar, como as outras crianças, do menino Jesus e dos anjos. Pelo contrário, só lhe tinham mostrado muitas vezes o crucificado, de tal modo que essa imagem era a única impressão que teve do

(Cf. MORÃO, Arthur. Advertência. In: KIERKEGAARD, Søren. Ponto de Vista explicativo da Minha Obra como Escritor. Lisboa: Edições 70, 1986, p.10; e T. H. CROXALL. Kierkegaard Commentary. New York: Harper and Brothers Publishers, 1956, p. xix).

${ }^{4}$ KIERKEGAARD, 1978, X2 A619, p.20.

${ }^{5}$ Ibidem, p. 20.

172 • Universidade Católica de Pernambuco 
Salvador; e, apesar de criança, já era velho como um homem idoso. Tal imagem acompanhou-o toda a sua vida; nunca pôde escapar à sua obsessão e jamais rejuvenesceu. ${ }^{6}$

Comentando a respeito do caráter tristonho e exageradamente escrupuloso que Kierkegaard recebeu em sua educação paterna, Giles ressalta acertadamente, que isso também se deveu ao fato de que Michael Pedersen sentia-se sob maldição divina porque, quando rapazinho, como pastor de ovelhas na região da Jutlândia, região árida e pobre da Dinamarca, experimentando fome e frio, subiu em uma colina e amaldiçoou a Deus. Até a morte, Michael não conseguiu se perdoar por isso. ${ }^{7}$ Mas precisamos destacar que o pai de Kierkegaard não foi apenas um homem severo e melancólico. O lar de Pedersen era um ponto de encontro onde ele recebia frequentemente a visita de líderes religiosos e políticos do seu tempo.

Pedersen procurou desenvolver as aptidões intelectuais dos seus filhos e mais disciplinarmente do seu filho caçula, com quem fazia muitas viagens imaginárias e a quem educou na arte da dialética. A esse respeito Kierkegaard desabafou: "Não conheci a imediatez; por conseguinte, de um ponto de vista estritamente humano, não vivi. Comecei imediatamente pela reflexão: não a adquiri um pouco com a idade: sou reflexão do princípio ao fim". 8

Kierkegaard herdou de seu pai, não somente a melancolia e a religiosidade, mas também o talento para a argumentação dialético-filosófica e uma imaginação criativa. É interessante percebermos que Kierkegaard escreveu muito em seus diários a respeito do pai, mas raramente escreveu sobre sua mãe. Em meio a toda a severidade da sua educação familiar, Kierkegaard também revelou ser alguém marcado pela emoção, pela paixão e pela sensibilidade. Nos seus escritos vemos alguém profundamente comprometido com a vida e constantemente consciente da importância de sua missão no mundo. ${ }^{9}$

${ }^{6}$ KIERKEGAARD, S. Dois Pequenos Tratados Ético-Religiosos. Em: PV, 125.

7 Cf. GILES, Thomas. História do Existencialismo e da Fenomenologia. São Paulo: EPU/EDUSP, 1975, p.6.

${ }^{8}$ KIERKEGAARD, 1986, p. 75.

${ }^{9}$ Cf. ROSA, Merval. Antropologia Filosófica: Uma Perspectiva Cristã. Rio de Ano $15 \cdot$ n. $1 \cdot$ jan./jun. $2015-173$ 
Aos 17 anos, em 1830, Kierkegaard matriculou-se na Universidade de Copenhague a fim de estudar teologia. Seus principais professores na Universidade foram: C. Sibbern, P. Martin Møller, e Hans L. Martensen. Sibbern e Møller, além de professores de filosofia, eram autores de ficção. Já Martensen, que foi consagrado Bispo-Primaz da Igreja Dinamarquesa, era considerado um hegeliano de renome, e acabou se tornando um grande inimigo teológico e filosófico de Kierkegaard.

Inicialmente saiu-se muito bem nos estudos, passando nos exames importantes com distinção, dedicando-se ao estudo da filosofia e da literatura. Desejava formar-se em Teologia como seu irmão Peter, que concluíra o curso em tempo reduzido e estava cursando o doutorando na Alemanha. Em 1834 a mãe de Kierkegaard morreu e então a sua fé desmoronou. Ele perdeu o ânimo com os estudos da Universidade, e acabou ingressando numa vida de esbanjamento em bares, restaurantes e festas onde gastava muito dinheiro com roupas e bebida, acumulando dívidas para serem pagas pelo seu pai. Esse foi um período de muita inquietação, dúvida e angústia para Kierkegaard, conforme ele mesmo afirmou: "Morte e inferno: posso fazer abstração de tudo, salvo de mim mesmo. Não posso me esquecer de mim nem quando durmo". ${ }^{10}$

Em 9 de Maio de 1838 Kierkegaard parece ter passado por algum tipo de experiência mística de conversão, que concretizou o reinício da sua caminhada de fé dentro do cristianismo. ${ }^{11}$ Qualquer que tenha sido tal experiência, isso significou que, após todos esses acontecimentos, Kierkegaard viu-se comprometido com a missão de expor o verdadeiro cristianismo: "...e por amor a meu pai, empenhei-me em expor o cristianismo da maneira a mais verdadeira, contrastando assim com todo esse palavrório que (na cristandade) se faz passar por cristianismo". ${ }^{2}$ Esta experiência levou Kierkegaard a se reconciliar com o seu pai, que nesse mesmo ano confessou-lhe os pecados referentes à sua conduta no passado. ${ }^{13}$

Janeiro: Juerp, 1994p. 156.

${ }^{10}$ KIERKEGAARD, 1978, 1 A162, p. 17.

${ }^{11}$ Ibidem, p. 17.

${ }^{12}$ Ibidem, p. 19.

${ }^{13}$ Tal reconciliação tem sido posta em dúvida. (Cf. GOUVÊA, 2000, nota 153).

174 • Universidade Católica de Pernambuco 
Michael Pedersen morreu em 9 de Agosto de 1838 e Kierkegaard interpretou essa morte como um "sacrifício" em seu favor. Ele escreveu a respeito, no dia 11 de Agosto de 1838, em seu diário: "Meu pai morreu na quarta-feira às duas da madrugada. Eu queria profundamente que ele vivesse ainda dois anos e vejo em sua morte o último sacrifício que seu amor fez por mim, porque não morreu para mim, mas por mim, para que eu possa, se ainda for possível, fazer qualquer coisa". ${ }^{14}$ Em 1838, após a morte do seu pai, Kierkegaard iniciou sua carreira como autor publicando uma crítica sua ao romance Apenas um tocador de violino de Hans Christian Andersen. O livro de Kierkegaard chamava-se Dos Papéis de Alguém Que Ainda Vive.

Mesmo herdando considerável fortuna, ele concretizou o desejo de seu pai e estudou com muita seriedade a fim de completar o curso na universidade. Em 3 de Julho de 1840 graduou-se em teologia e em 1841, três anos após a morte do seu pai, recebeu o título de Mestre em Filosofia (Magister), com a tese sobre o Conceito de Ironia constantemente referido a Sócrates. ${ }^{15}$

Em 10 de Setembro desse mesmo ano anunciou o seu noivado com a jovem Regine Olsen. Mas em 11 de Outubro de 1841, Kierkegaard rompeu oficialmente o seu compromisso com ela. O rompimento do noivado com Regine, a quem amava, foi um incidente crucial na vida de Kierkegaard e o inspirou na produção de muitas das suas obras. ${ }^{16} \mathrm{O}$ rompimento do noivado com Regine desempenharia um papel importante no desenvolvimento da vida e obra de Kierkegaard. Isso é evidente nas muitas anotações em seu diário, e referências disfarçadas reaparecem com frequência em

\footnotetext{
${ }^{14}$ KIERKEGAARD, 1978, II A243, p. 17.

15 Apresentado e traduzido para o português por Álvaro L. M. Valls, Petrópolis, RJ:Vozes, 1991. A respeito da conclusão do seu curso Kierkegaard escreveu em seu diário: "Após a morte do meu pai, Sibbern me disse: 'Agora nunca mais você obterá o diploma de teologia'. Mas, foi precisamente por causa da morte de meu pai que eu o obtive. Se meu pai continuasse vivo jamais eu teria conseguido o diploma". (DP, VI AB, p.18).

${ }^{16}$ A razão que levou Kierkegaard a romper seu noivado com Regine ainda não é totalmente conhecida. Provavelmente ele entendeu que era um desejo de Deus. Regine seria identificada com Isaque, filho que deveria ser sacrificado por Abraão, no cumprimento da vontade soberana de Deus ou então, como ele revela em seu diário, talvez se achasse incapaz de ser um bom marido devido às angústias e crises familiares e pessoais (KIERKEGAARD, 1978, p. 25).
} 
seus textos.

Após romper com Regine, ele viajou no dia 25 de Outubro do mesmo ano para Berlim, onde no mês seguinte assistiria um curso do filósofo idealista Schelling, na Universidade de Berlim. Seus companheiros de classe foram, dentre outros, Feuerbach, Engels e Bakunin. Schelling estava naquele tempo se opondo às ideias de Hegel. A reação de Kierkegaard acerca da filosofia de Schelling não foi das melhores. À medida que as aulas de Schelling iam da crítica negativa à especulação positiva, Kierkegaard passou a considerá-lo confuso e arrogante. Ele regressou de Berlim em 6 de Março de 1842 a fim de concluir uma de suas obras mais importantes e a primeira pseudonímica A Alternativa (Either/Or).

A partir de Dezembro de 1845 Kierkegaard ingressou num período muito difícil da sua vida. Naquele mês um antigo conhecido, P. L. Møller publicou um artigo crítico a respeito do Livro Estações No Caminho da Vida de Kierkegaard, onde também mencionava coisas a respeito da vida pessoal do autor. Møller afirmou que Kierkegaard tratara Regine com crueldade. Kierkegaard não resistiu e escreveu uma resposta, que foi publicada num jornal local, onde ele, dentre outras coisas, revelou que Møller colaborava anonimamente para o jornaleco $O$ Corsário, conhecido pelos seus ataques contra a elite de Copenhague, tendo por objetivo ridicularizá-la. Isso prejudicou a reputação de Møller. No final do artigo Kierkegaard desafiou o jornal $O$ Corsário a atacá-lo. Meir Goldschmidt, o editor daquele jornal, admirava Kierkegaard, mas quando este escreveu que ser louvado pelo jornal $O$ Corsário equivalia a um insulto, Goldschmidt promoveu uma ridicularização constante e ofensiva contra Kierkegaard. A partir de então, ele se tornou um dos alvos preferidos do jornal. Foram feitas caricaturas com o intuito de zombá-lo e artigos foram escritos ridicularizando o seu intelecto. O jornal saiu de circulação no mesmo ano, mas Kierkegaard foi tremendamente humilhado. Nos Diários e Papéis ele escreveu:

Mesmo o assistente do açougueiro acha-se no direito de me ofender devido ao $O$ Corsário. Estudantes de faculdade sorriem, gracejam e deliciam-se porque alguém está sendo pisoteado; os doutos são invejosos e secretamente simpatizam com o ataque, ajudando a espalhá-lo. Acrescentam, é claro, que se trata de uma clamorosa vergonha. A menor coisa que eu faça, 
mesmo se for uma simples visita, é mentirosamente distorcida e repetida amiúde; se $O$ Corsário fica sabendo, a mentira é impressa e lida por toda a população". 17

Os últimos anos da vida de Kierkegaard foram marcados por sua luta contra a cristandade nominal da Igreja Oficial da Dinamarca. Tudo decorreu porque o bispo J. P. Mynster (17751854), que foi grande pregador e escritor devocional de renome, veio a falecer. Dois dias antes do sepultamento de Mynster (que ocorreu em 7 de Fevereiro de 1854), o seu sucessor Martensen foi designado para fazer um elogio fúnebre a respeito de Mynster, e chamou-o, dentre outras coisas, de 'testemunha da verdade' (Sandhedsvidne), cuja cadeia de testemunhos se estende desde os dias apostólicos até hoje".

A peculiaridade quanto ao termo "Sandhedsvidne" é que, naquela época, ele não podia ser encontrado em nenhum dicionário dinamarquês simplesmente por ser de recente cunhagem por Kierkegaard. Em seu Ataque Contra a Cristandade, Kierkegaard explica que este título "havia sido inventado por ele para caracterizar aqueles mártires e apóstolos que, em seu sofrimento, 'testemunharam' a verdade do cristianismo", o que se aplicado a Mynster representaria um exagero, um absurdo e uma falsificação. No artigo Foi o Bispo Mynster uma "testemunha da verdade", uma das "genuínas testemunhas da verdade" - isto é verdade?, Kierkegaard escreveu:

Uma testemunha da verdade é um homem cuja vida do início ao fim desconhece tudo o que é chamado deleite (...) do início ao fim ele é iniciado no sofrimento(...). Uma testemunha da verdade é um homem que na pobreza testemunha a verdade - na pobreza, na humildade, no rebaixamento, e assim não é apreciado, é odiado, desprezado e então é detestado, insultado, zombado - talvez não tenha sempre o seu pão diário, por ser um homem pobre, mas com o pão diário da perseguição ele é provido todos os dias. (...) Uma testemunha da verdade, uma das genuínas testemunhas da verdade, é um homem que é

17 DRU, Alexander. The Journals of Kierkegaard. New York: Harpers \& Brothers, 1959, p.103. 
escorraçado, maltratado, arrastado de uma prisão para outra (...) então por fim crucificado, ou decapitado, ou queimado, ou calcinado sobre uma grade, seu corpo sem vida jogado pelo carrasco num lugar ermo...ou queimado até as cinzas e jogado aos quatro ventos, para que qualquer traço do "impuro" seja obliterado. ${ }^{18}$

Daí em diante travou-se uma enorme batalha (o Kirkecamp) entre Kierkegaard e a Igreja dinamarquesa. Em 1854 Kierkegaard começou a publicar artigos no jornal; e posteriormente publicou nove fascículos do panfleto intitulado $O$ Momento (Øjeblikket) que circulou de Maio a Setembro de 1855, nos quais atacava de forma impiedosa a Igreja estatal da Dinamarca e através do qual procurava restaurar o sentido original do cristianismo.

Para ele, a cristandade de sua época era uma caricatura do cristianismo autêntico ou um imenso conglomerado de erros e ilusões, nos quais havia uma pequena dose de cristianismo verdadeiro. O seu ataque contra a Igreja chamou a atenção de pessoas dentro e fora da Dinamarca até que, em 2 de Outubro de 1855, Kierkegaard teve um colapso nervoso e foi recolhido sem sentidos na rua e levado para o Hospital Frederik. Ali, recebeu por diversas vezes a visita de seu amigo de infância o pastor Emil Boesen, com quem manteve seus últimos diálogos. Em 19 de Outubro Boesen perguntou a Kierkegaard se este desejava receber a comunhão. Ele respondeu que desejava recebê-la das mãos de um leigo, não de um pastor. Boesen replicou que isso não estava certo, mas Kierkegaard disse que então morreria sem recebê-la.

Kierkegaard faleceu num domingo, em 11 de Novembro de 1855 e foi sepultado, no Cemitério da Assistência, sete dias depois com funerais solenes na catedral episcopal da Igreja de Nossa Senhora (Vor Frue Kirke). ${ }^{19}$ Quando ele morreu em 1855, estava pobre, mas o que restou da sua herança foi deixado por ele para Regine.

\footnotetext{
${ }^{18}$ KIERKEGAARD, Soren. Attack Upon Christendom. Trad. de Walter Lowrie. Londres: Oxford University Press, 1946, p.7.

${ }^{19}$ Cf. REICHMANN, Ernani. Intermezzo Lírico-Filosófico. Curitiba: Edição do autor, 1963p. 12.

178 • Universidade CATÓlica dePernambuco
} 


\section{A "missão" de Kierkegaard}

Kierkegaard via a si mesmo como como um escritor e pensador com uma missão a cumprir. E qual a sua missão? Thomas Giles, a partir do Pós-Escrito, destaca que Kierkegaard não teve como objetivo elaborar um sistema que advogasse ser o fundamento exclusivo da sabedoria. A tarefa e missão do nosso filósofo seriam mais modestas: "mostrar que uma vez um homem viu o que significa existir". Tomando isso como ponto de partida, Kierkegaard lançaria mão de diversas formas para tentar comunicar o verdadeiro significado da existência, embora, como acertadamente afirma Giles, isso não indicasse necessariamente que ele já o houvesse alcançado. ${ }^{20}$ A vocação filosófica de Kierkegaard, teria um chamado irresistível para desenvolver-se no âmbito da concretude da existência em seus limites e possibilidades.

Falando acerca desta vocação, Álvaro Valls destaca que a conversa entre Kierkegaard, então com 16 anos, e o cientista Peter Lund $^{21}$ foi decisiva para a opção vocacional do jovem Søren. Seis anos mais tarde, em 1835, Kierkegaard, em sua carta ao dr. Lund, registrava que, embora fosse maravilhoso dedicar-se às ciências naturais, o que mais lhe importava era o problema enigmático da vida enquanto razão e liberdade. ${ }^{22}$ Em seus Papirer, ele revela a sua busca de uma vida com profundo significado existencial:

$\mathrm{O}$ que me falta é, no fundo, ver claramente em mim mesmo o que devo fazer e não o que devo conhecer, salvo na medida em que o conhecimento sempre precede a ação. Trata-se de compreender o meu destino, de ver o que Deus quer propriamente que eu

${ }^{20}$ Cf. GILES, 1975, p.11.

${ }^{21}$ O Dr.Lund nasceu em Copenhague em 14 de Junho de 1801. Estudou medicina e sabendo-se tuberculoso, mas com recursos financeiros, veio ao Brasil em 1825. Em 1827 voltou à Dinamarca. Nesse ano, na casa de Henrik Ferdinand Lund, casado com Pétrea Severine (irmã de Kierkegaard), Kierkegaard, com a idade de 16 anos e o dr.Lund se conheceram, tendo uma longa conversa. Em 1833 Lund voltou ao Brasil definitivamente. Em 1835, Kierkegaard escreveu-lhe uma carta que não foi enviada. Lund viveu em Minas Gerais e pesquisou durante 50 anos nossa flora e fauna e as cavernas da região de Lagoa Santa. (Cf. REICHMANN, p. 357 e VALLS, Álvaro. Entre Sócrates e Cristo: Ensaios sobre a Ironia e o Amor em Kierkegaard. Porto Alegre: Edipucrs, p.11).

${ }^{22}$ Cf. VALLS, p. 11. 
faça, isto é, de encontrar uma verdade que seja verdade para mim, de encontrar a ideia pela qual quero viver e morrer. ${ }^{23}$

Ele desejava emergir do mar da inautenticidade, do conformismo do povo em geral, tomando sobre seus ombros todo peso do existir concreto, consciente de si e do mundo ao seu redor. Desta forma, a obra de Kierkegaard não estabelece proposições e teorias racionais alheias à vida concreta do ser humano.

Neste sentido, Kierkegaard revela a vocação de todos os verdadeiros filósofos, que está na origem mesma da filosofia. Filosofar pressupõe a inquietação que atinge um determinado indivíduo, que lhe rouba a adequação tranquila e conformada em meio à natureza que segue instintivamente e fatalmente o seu rumo. O jovem Kierkegaard terá toda a sua vida abalada por causa da consciência de si mesmo enquanto existente. Existir é situar-se em meio às coisas e ao geral humano. Em sua luta em prol da conquista da sua própria existência, Kierkegaard produziu uma obra sui generis.

Meu mérito literário será sempre o de ter exposto as categorias decisivas do âmbito existencial com uma agudeza dialética e uma originalidade que não se encontram em nenhuma obra literária, ao que eu saiba, pelo menos. Também não me inspirei em obras alheias. Acrescente-se a isso minha arte de expor, sua forma, e realização lógica, mas levará muito tempo antes que alguém encontre lazer suficiente para lê-la e estudá-la seriamente. Nesse sentido minha produtividade será, quem sabe até quando, desprezada, como o prato delicado que se serve ao camponês. $^{24}$

O desenvolvimento da temática da existência em Kierkegaard termina por obviamente confrontar-se com outras concepções de existência que nada mais são do que meras caricaturas que se recusam a revelar a sua inautenticidade existencial. E como a tese de Kierkegaard é que a autenticidade

\footnotetext{
${ }^{23}$ KIERKEGAARD, 1978, IA75, p. 39.

${ }^{24}$ KIERKEGAARD, 1978, VII A127, p.42.

180 • Universidade Católica de Pernambuco
} 
encontra-se apenas no estágio do existir religioso, a sua obra está fundamentada no pressuposto da necessidade da nossa relação com o Absoluto, entendido como o Deus revelado pelo cristianismo. A sua atividade literária terá principalmente o encargo de deixar claro o que significa existir religiosamente e isso não deve ser entendido em termos da religiosidade objetiva ou oficializada. Kierkegaard cria ser um dever esclarecer que a sua produção revelava que ele havia sido um autor religioso. No Ponto de Vista Explicativo da Minha Obra como Escritor ele explica a verdadeira intenção da sua obra:

Esta pequena obra propõe-se, pois, dizer o que sou verdadeiramente como autor, que fui e sou um autor religioso, que toda a minha obra de escritor se relaciona com o cristianismo, com o problema de tornar-se cristão, com intenções polêmicas diretas e indiretas contra a formidável ilusão que é a cristandade, ou a pretensão de que todos os habitantes de um país são, tais quais, cristãos. ${ }^{25}$

A sua missão, segundo ele, seria a de "limpar o terreno" para que o verdadeiro cristianismo pudesse aflorar. Ao usar esta expressão, talvez ele esteja fazendo referência ao mesmo termo que foi usado em relação ao profeta e mártir João Batista. Este não era apóstolo, mas pregou na solidão do deserto, a fim de limpar o caminho para Deus, e também teve a coragem necessária para denunciar a hipocrisia dos fariseus e saduceus que eram os líderes religiosos populares do seu tempo, bem como a dubiedade de caráter moral do poderoso rei Herodes. ${ }^{26}$ Portanto, tal como $o$ batista, Kierkegaard se vê apenas como um precursor, não se considera alguém nomeado por Deus, mas mesmo assim, vê-se a serviço de Deus.

Minha missão: "Limpar o terreno" - Não sou um apóstolo que anuncia algo em nome de Deus e com autoridade. Não, estou a serviço de Deus. Minha missão - é de limpar o terreno, para que Deus possa avançar (À margem, minha missão não é a de limpar o terreno com os meios comuns, mas por meio do

\footnotetext{
${ }^{25}$ KIERKEGAARD, 1986, p. 22.

${ }^{26}$ Cf. Evangelho de Mateus 3.1-10.
} 
sofrimento). Deduz-se então facilmente porque devo ser literalmente um homem sozinho e mantido em grande fraqueza e debilidade. ${ }^{27}$

Todo esse esforço de Kierkegaard tinha razão de ser no fato de que ele considerava o cristianismo na Dinamarca daqueles dias uma verdadeira aberração. Como ele mesmo diz em $O$ Momento $\mathrm{n}^{\circ}$ 10: "Minha tarefa é socrática. Ela consiste em revisar a noção do que é ser um cristão: não digo que sou um cristão (na salvaguarda do ideal), mas posso mostrar que os outros o são menos do que eu". ${ }^{28}$

Para ser mais exato, Kierkegaard via a si mesmo como um legista a exumar os restos mortais do cristianismo. Não que ele descresse que em algum lugar ainda houvesse o verdadeiro cristianismo, mas, de forma hiperbólica e com o intuito mesmo de impressionar os seus contemporâneos que se consideravam cristãos apenas por serem dinamarqueses, ele protestava contra a adulteração e falsificação do verdadeiro espírito do cristianismo. Sobre isso, em Janeiro de 1855, ele afirmou drasticamente no artigo A Situação Religiosa: "O cristianismo não existe mais. A situação religiosa em nosso país é: o cristianismo (isto é, o cristianismo do Novo Testamento - e qualquer outra coisa não é cristianismo, muito menos por assim chamar), cristianismo não existe - como qualquer um deve ser capaz de ver tão bem quanto eu". ${ }^{29}$

Assim, enquanto dr. Lund estabelecia uma relação de exumação do mundo dos fósseis, que jazia enterrado e esquecido em meio à exuberância da floresta brasileira, ele, Kierkegaard, qual verdadeiro cientista da vida, exumava as categorias do verdadeiro cristianismo, que em sua concepção estava esquecido e morto na Dinamarca, enquanto a cristandade exibia as folhagens de uma apenas aparente exuberância religiosa:

Assim como ele vive no Brasil; perdido para o mundo, mergulhado nas escavações dos estratos antediluvianos, assim vivo eu, como se estivesse fora do mundo, perdido a exumar os conceitos cristãos. Ai de mim! - e dizer que vivo na cristandade, onde o

\footnotetext{
${ }^{27}$ KIERKEGAARD, 1978, X12A250, p.46.

${ }^{28}$ KIERKEGAARD, 1946, p.283.

${ }^{29}$ Ibidem, p. 29.

182 • Universidade CAtólica de Pernambuco
} 
cristianismo está em plena floração, ergue-se em sua exuberância, com seus mil pastores e onde todos somos cristãos. $^{30}$

Portanto, vemos na obra de Kierkegaard dois dos eixos temáticos que figuram dentre os mais importantes do debate filosófico ocidental: a questão das categorias centrais da existência e a da possibilidade de relação entre o indivíduo e o Absoluto. Ele previu, acertadamente, que seria lido e estudado no futuro, justamente porque a sua existência teria sido mais interessante do que a de qualquer outro escritor na Dinamarca. No Diário ele afirma: "Eu ataco os demais precisamente porque, em lugar de servirem-se das fontes, para seus estudos, utilizam os compêndios minha própria vida não é senão um compêndio - quando consigo vencer em qualquer discussão, o fantasma de minha própria fantasia cai em meus braços sem que nenhum argumento baste para libertar-me dele". 31

\section{Metodologia filosófica e literária}

Para uma melhor compreensão da obra kierkegaardiana não poderemos desconhecer o seu método, pois este é fundamental por estar radicalmente relacionado com a sua perspectiva quanto ao que significa ser um existente. O método kierkegaardiano tem por objetivo partir do pensamento para a ação, e a ação pressupõe um ato de vontade. A esse respeito Álvaro Valls afirma que, já na sua dissertação sobre o conceito de ironia pode-se perceber que, ali se encontra o método, bem como as técnicas da maiêutica:

Kierkegaard está convencido de não ter uma doutrina propriamente nova ou uma teoria recém-inventada para ensinar. Recusa-se à "comunicação magistral". A pessoas com indigestão, diz ele, é preciso receitar um vomitório, e não mais comida. Seu esforço é socrático, provocar, interrogar, refutar, conversar com todo o mundo, nas revistas, na literatura, nos jornais, nos bares e nas calçadas das ruas de sua cidade, na Universidade de Berlim, nos teatros ou nas tabernas

\footnotetext{
${ }^{30}$ KIERKEGAARD, 1978, X3A239, p.45.

${ }^{31}$ Ibidem, p. 39.
} 
Kierkegaard, assim como Sócrates que afirmava nada saber, procurava negar que era um cristão (isto é, se comparado à concepção de cristianismo vigente em sua época, na Dinamarca). Kierkegaard assume assim uma postura irônica (no sentido socrático) como metodologia, como forma de comunicação e, até mesmo, como modo de ser perante os cidadãos dinamarqueses.

Quando vier o leitor amigo, não terá dificuldade em ver que, quando passei por um ironista, a ironia não estava de modo algum onde julgava um venerável público cultivado; para semelhante leitor, é evidente que não iria cair na miséria de admitir que um público possa entender de ironia, o que é tão impossível como existir em massa o Indivíduo; verá que a ironia consistia no fato de, neste autor estético e sob a sua "Erscheinung" (aparência) de mundanidade, se esconder o autor religioso que, exatamente nesta época, se entregava para sua edificação a tanta religiosidade, talvez como uma família inteira. Verá, além disso, que a ironia se encontra na sequência e justamente naquilo que o respeitável público cultivado tinha como demência. Numa época de ironia (esta grande assembleia de loucos) o ironista verdadeiro não tem outra coisa a fazer senão resolver toda a situação, tornando-se ele próprio o objeto da ironia geral. $^{33}$

Assim, em suas obras estéticas - que objetivam demover os estetas ao primeiro passo na caminhada à autenticidade, Kierkegaard procura expor a verdade sem expô-la diretamente, "escondendo-se", como o fizera Sócrates, em uma atitude irônica perante o mundo. Como acertadamente o expressa Valls: "A ironia o ajuda, como os atores de teatro, a dar sua interpretação sobre a existência. Ela lhe permite, entre outras alternativas, assumir a visão e a atitude apaixonada da fé". ${ }^{34}$ A sua "missão" estabelecerá o seu modo de se comunicar com os seus interlocutores e leitores e,

\footnotetext{
${ }^{32}$ VALLS, p.17.

${ }^{33}$ Citado em VALLS, p.33.

${ }^{34}$ Ibidem, p.34.

184 • Universidade Católica de Pernambuco
} 
dependendo do seu telos filosófico-teológico-existencial, irá determinar se a sua comunicação se dará de forma direta ou não.

\subsection{A distinção entre comunicação direta e indireta}

A grande preocupação de Kierkegaard foi comunicar de tal forma que os seus leitores se sentissem impelidos a agirem existencialmente, entrando numa relação pessoal com a verdade e deixando de ser espectadores da vida ou meros números dissolvidos no geral. Por isso, a relação entre pensamento e ação irá determinar se o método de comunicação será direto ou indireto.

De acordo com Kierkegaard, há conhecimentos que estão mais relacionados com a ação do que outros. Os tipos de conhecimento são os seguintes: o acidental, sem qualquer efeito sobre a ação humana, e o essencial, que se orienta para a ação e está relacionado à subjetividade e à existência da pessoa como ser moral. Neste caso, com relação à significação moral, apenas o conhecimento ético-religioso tem relação essencial com o conhecedor. $\mathrm{O}$ conhecimento meramente especulativo não afeta a ação humana de forma direta. ${ }^{35}$

O ponto nevrálgico é que, para ele, esse tipo de conhecimento que faz a diferença na vida, só pode ser comunicado indiretamente, buscando atingir a vontade que leva à ação, e não apenas o intelecto. Desta forma, o indivíduo é levado a se apropriar do que até então se relacionava com o eu superficialmente. ${ }^{36}$ A sua grande preocupação não é com a verdade científica objetiva, mas com a verdade que se instala na subjetividade, verdade que não é um mero resultado de proposições. A verdade que é achada na dimensão da existência e só pode ser conquistada por um ato de vontade do eu. Climacus (um dos pseudônimos de Kierkegaard) explica a diferença entre a abordagem fundada na objetividade e a abordagem indireta subjetiva. Para ele, o pensamento objetivo é completamente indiferente à subjetividade, portanto, sua comunicação é direta, pois ele não possui a arte da dupla reflexão. Nesse aspecto, o pensamento objetivo portanto só está ciente de si

\footnotetext{
${ }^{35}$ Cf. ROSA, 1994, p.158.

${ }^{36}$ ROSA, 1994, p.158.
} 
mesmo e portanto não é comunicação.

Como autor, Kierkegaard estruturou a sua obra com objetivos bem claros em mente. Para ele, a cristandade dinamarquesa era uma ilusão. Tais pessoas viviam sem qualquer compromisso verdadeiro com a autenticidade religiosa, sob categorias inteiramente diversas daquelas que garantiriam a fundamentação da existência.

Que significa que tantos milhares de homens se digam cristãos sem mais dificuldades! Como podem obter este nome inúmeros homens, cuja imensa maioria, segundo tudo leva a crer, vive sob categorias tão diferentes, como o demonstra a mais superficial observação! Como o podem eles, homens que talvez nunca vão à igreja, nunca pensam em Deus, nunca pronunciem o seu nome, senão para blasfemar! Como o podem eles, homens que nunca compreenderam que podem ter na sua vida uma obrigação para com Deus, e que fazem de uma certa integridade física o máximo do seu ideal, se nem mesmo acham absolutamente necessária! Todos, no entanto, até os que negam Deus, são cristãos, dizem-se cristãos, são reconhecidos como cristãos pelo Estado, são enterrados como cristãos pela Igreja, são enviados como cristãos para a eternidade! ${ }^{38}$

A proposta do filósofo seria a de atacar o âmago de tal inautenticidade, mas não drasticamente de forma direta. $\mathrm{O}$ ataque direto apenas faria com que as pessoas se agarrassem ainda mais aos seus pontos de vistas ilusórios e fatalmente enganosos, aumentando-lhes a tendência da manutenção do status quo existencial: "O ataque direto não faz mais do que ancorar o homem na sua ilusão, exasperando". ${ }^{39}$ Além disso, o ataque direto também não garantiria a conquista da verdade no silêncio da interioridade. A ilusão, para Kierkegaard, só pode ser devidamente destruída pelo método indireto "que servindo o amor da verdade, observa na sua dialética todas as espécies de atenções para com o homem iludido e que, com o pudor próprio do amor, se retira para não ser

${ }^{37}$ Cf. GOUVÊA, 2000, p.192-3.

${ }^{38}$ KIERKEGAARD, 1986, p.37-8

${ }^{39}$ Ibidem, p.39.

186 • Universidade Católica dePernambuco 
testemunha da confissão que o interessado a si próprio faz, sozinho diante de Deus, quando reconhece que viveu na ilusão". 40

O método indireto significa que o nosso autor desce da sua tribuna crítica, sem expressar juízo de valor pessoal, para viver entre os seus leitores, aos quais deseja conclamar a uma mudança de mente, a uma nova atitude perante a vida: "Se todos estão na ilusão, dizendo-se cristãos, e se é necessário trabalhar contra isso, esta noção deve ser dirigida indiretamente, e não por um homem que proclama bem alto que é um cristão extraordinário, mas por um homem que, mais bem informado, declara que não é cristão". 41

Por isso, sua obra deve principiar na dimensão existencial em que os seus leitores, a princípio, ilusoriamente se encontram: "Se, pois, por hipótese, a maioria dos cristãos só o são em imaginação, em que categorias vivem eles? Nas da estética ou, quando muito, nas categorias estético-éticas". 42 Depois disso, torna-se necessário apresentar as limitações do estético e do ético e a autenticidade do religioso.

A comunicação, inicialmente indireta e só depois direta, tem por objetivo a reflexão cujo universo é o interior, qual tormenta revolucionária que ocorre no eu. Essa reflexão tem por alvo levar o leitor a encontrar a verdade existencial. Para Kierkegaard, se a verdade é uma realidade existencial pessoal e viva, ela não deve ser comunicada como uma doutrina, mas como uma alternativa a ser escolhida, como uma possibilidade a ser realizada. $\mathrm{O}$ seu intuito maior é o de despertar o leitor para a reflexão sobre a sua própria existência:

Quando, pois, um homem vive nessa ilusão [de que todos são cristãos], por conseguinte, eram categorias puramente estéticas de todo diferentes das cristãs, que acontece se, pela sua produção estética, um autor é capaz de o cativar e de o ganhar completamente, depois, de apresentar o religioso com tanto desembaraço que o outro, no rumo para que se deixa conduzir, corre diretamente para as determinações mais decisivas do religioso? Que acontece? Este homem torna-se necessariamente atento. Apesar de

\footnotetext{
${ }^{40}$ Ibidem, p.39-40..

${ }^{41}$ Ibidem, p.39.

${ }^{42}$ Ibidem, p.39.
} 
tudo, ninguém pode predizer o resultado; mas a atenção está forçosamente despertada. ${ }^{43}$

Para existir autenticamente é necessário o conhecimento interior daquilo que se é, ou seja, de que se é síntese do finito e do infinito; e tal conversão filosófico-existencial não se dá a não ser no âmbito da interioridade sacudida pela reflexão. Para Kierkegaard, qualquer comunicação direta com respeito à verdade como interioridade leva a uma má compreensão. A comunicação direta sobre o que significa existir e sobre a interioridade tenderá à especulação, embora a libertação da ilusão só se dê igualmente mediante a reflexão.

O método indireto é o segredo da maiêutica, levando o que o emprega a se humilhar perante aquele a quem quer ajudar, pois ajudar não é dominar, mas servir. Com o intuito de ajudar seus leitores Kierkegaard constrói a sua obra. Mas, ajudar não é mostrarse ambicioso, pelo contrário, é ser extremamente paciente, acatando uma postura que provisoriamente está errada e que ignora as coisas que o outro compreende. ${ }^{44}$ Desta forma, Kierkegaard repete, em parte, a pedagogia de Sócrates, dirigindo-se aos seus leitores como um dentre eles e não como alguém que está numa posição de superioridade. Esta pedagogia da existência revela que o mestre não está numa posição superior pois ele também aprende com o discípulo em seus passos rumo à autenticidade. Acerca do método maiêutico de Kierkegaard, Ernani Reichmann afirma:

Este é o segredo da maiêutica kierkegaardiana: o método indireto, que foi aprender com Sócrates. E é assim que Kierkegaard introduz a todos no problema religioso, como queria, sem que o leitor perceba para onde está sendo conduzido através de uma dialética que alcança momentos de rara perfeição, como nessa obra tão conhecida que é "Temor e Tremor". Obra estética, Temor e Tremor? É o que nos diz Kierkegaard. Mas, de qualquer modo, não há quem não sinta o problema religioso suspender o problema ético, no desenvolvimento lírico-dialético dessa obra realmente maravilhosa. Todo o pensamento de

${ }^{43}$ KIERKEGAARD, 1986, p. 46.

${ }^{44}$ KIERKEGAARD, 1986, p.41.

188 • Universidade Católica de Pernambuco 
Kierkegaard mostra, por conseguinte, essa unidade extraordinária de sentido: tornar-se cristão. ${ }^{45}$

Para Kierkegaard, tudo se encontra no plano da reflexão. E como a comunicação se faz neste plano ela é, portanto, indireta. A partir da reflexão Kierkegaard está numa posição negativa. Ele não afirma ser um excelente cristão nem postula falar em nome de Deus (pois se trataria de comunicação direta). Ao contrário, ele chega a dizer que não é cristão. Na verdade, o grande problema que alimenta a sua reflexão é: a partir de dentro do cristianismo, chegar a ser um verdadeiro cristão. Por isso, a obra pseudonímica de Kierkegaard é apresentada ao leitor por meio da comunicação indireta, com o objetivo de levá-lo a uma decisão existencial autônoma e pessoal.

Mas, é necessário o devido cuidado acerca da extensão do caráter ambíguo dos escritos indiretos de Kierkegaard. Mas, o seu objetivo não era produzir uma filosofia esvaziada de qualquer objetividade. Para Kierkegaard, na comunicação direta transmite-se um saber, ao passo que, na indireta busca-se atingir as profundezas da subjetividade, a interioridade, e a sua tarefa é o despertamento da consciência existencial do indivíduo; o que lhe remete às temáticas da eternidade e do dever para com Deus. ${ }^{46}$

É preciso, entretanto, destacar que a comunicação indireta não constitui o todo da obra de Kierkegaard. Como ele mesmo afirmou, a comunicação deve, mais cedo ou mais tarde, acabar em comunicação direta. Isso ele fez, desde o início paralelamente, em seus discursos construtivos e, de forma explícita com a sua produção puramente religiosa. Por isso a obra de Kierkegaard foi dividida por ele mesmo em três grupos: o primeiro, de natureza estética; o segundo grupo é somente formado pelo Pós-Escrito Não-Científico Conclusivo que é o ponto crítico, e o terceiro grupo apresenta sua produção restritamente religiosa. ${ }^{47}$

\footnotetext{
${ }^{45}$ REICHMANN, 1963, p.25.

${ }^{46}$ Cf. HUISMAN, Denis. Dicionário de Obras Filosóficas. São Paulo: Martins Fontes, 2000, p. 374.

${ }^{47}$ KIERKEGAARD, 1986, p. 29-30.
} 


\subsection{O emprego da heteronímia}

A comunicação indireta, primeiro passo no esforço profético-reformador de Kierkegaard, se deu, como sabemos, através do uso de diversos pseudônimos - personagens representativos dos diversos estágios da existência. Devido ao uso de pseudônimos, a obra kierkegaardiana constitui-se num desafio, pois em seu estudo é preciso identificar se o pensamento apresentado é o do próprio Kierkegaard ou se é uma afirmação de uma posição contrária à dele. Isto porque, os seus pseudônimos representam, como num teatro, personagens com ideias próprias, estabelecendo-se uma dialética entre esses personagens.

Quanto ao uso literário da heteronímia, Croxall comenta que tal recurso era um tipo de moda naqueles dias entre os escritores românticos, mas que Kierkegaard não teria usado este recurso literário apenas para seguir a tendência da época. Nos Diários e Papéis, ele deixa claro que, em vez de apresentar teoricamente diferentes pontos de vista, preferiu criar e apresentar aos leitores diversas personagens que representavam aquelas diferentes perspectivas. Cada um deles é uma entidade completa, a tal ponto que podemos estudar a individualidade de cada uma delas e através de seus muitos juízos (cada qual só relativamente verdadeiro) poderemos chegar às nossas próprias conclusões. ${ }^{48}$

Cada heterônimo, portanto, é vividamente retratado de acordo com o estágio existencial que Kierkegaard deseja examinar. Assim, Johannes Climacus trata da relação entre a dúvida e a fé. Vigilius Haufniensis lida com os aspectos psicológicos do pecado e da ansiedade. Johannes de Silentio e Constantin Constantius aborda a ética, a partir dos aspectos envolvidos no relacionamento de Kierkegaard com Regine Olsen. Anti-Climacus é o cristão ideal, etc. Com isso, Kierkegaard queria que os seus leitores se identificassem com os seus personagens e para isso criou mais de vinte personagens. Cada um deles foi cuidadosamente forjado a fim de ser um indicativo das possíveis situações existenciais. Porém, mesmo usando heterônimos, é possível que a autoria de Kierkegaard nunca fosse realmente um segredo para os habitantes de Copenhague. A esse respeito sugere Louis Mackey:

${ }^{48}$ Cf. CROXALL, 1956, p.7.

190 • Universidade Católica de Pernambuco 
Um pseudônimo kierkegaardiano é uma persona, uma pessoa imaginária criada pelo autor com propósitos artísticos, não um nom de plume, um nome fictício usado para proteger sua identidade pessoal dos perigos e embaraços da publicidade. Quando Kierkegaard assinava seus livros com nomes impossíveis como Johannes de Silentio (João de Silêncio) e Vigilius Haufniensis (Vigia de Copenhague), ninguém no pequeno e fofoqueiro mundo das letras da Dinamarca tinha a menor dúvida sobre sua origem. Nem ele queria que tivessem; seu propósito não era a mistificação mas a distância. ${ }^{49}$

\section{O Corpus Kierkegaardiano}

Quando Kierkegaard morreu em 1855 parecia pouco provável que sua obra sobrevivesse e fosse difundida. Os seus livros foram escritos em dinamarquês, um idioma pouco conhecido fora do seu país, onde Kierkegaard havia chegado a ser uma figura popular, muito mais pelas suas polêmicas do que pela qualidade filosófica dos seus escritos. ${ }^{50}$ Mas hoje, ele é considerado um dos pensadores mais importantes na história da Filosofia. Os seus escritos formam cinco grandes grupos ${ }^{51}$ :

a) Os primeiros escritos, 4 obras, (1834-1841): Artigos dos tempos de estudante; A batalha entre os velhos e os novos depósitos de sabão; Dos papéis de alguém que ainda vive; O conceito de Ironia.

b) as obras pseudonímicas ou estéticas, 9 obras, (1843-1846), onde ele cria não só histórias, mas também os autores dessas histórias e onde ele usa o método da comunicação indireta: A Alternativa; Temor e Tremor; Repetição; É preciso duvidar de tudo; Migalhas filosóficas; $O$ conceito de angústia; Prefácios; Estações na estrada da vida; Pós-Escrito não-científico conclusivo.

${ }^{49}$ MACKEY, Louis. Kierkegaard: A Kind of Poet. Philadelphia: University of Pennsylvania Press, 1971, p. 247.

${ }^{50}$ Cf. ROUBICZEK, P. El Existencialismo. Barcelona: Editorial Labor, 1968, p.59.

${ }^{51}$ Seguirei a classificação feita por GOUVÊA, 2000, p.229.

Ano 15・n. $1 \cdot$ jan./jun. 2015 - 191 
c) as obras veronímicas, 14 obras, (1843-1855), onde ele se apresenta pessoalmente e o seu método é o da comunicação direta: Dezoito discursos edificantes; Três discursos em oportunidades imaginárias; Uma resenha literária de Duas Eras; Discursos edificantes em variados estados de espírito; Obras de amor; Discursos cristãos; O lírio do campo e a ave do céu; Três discursos para a comunhão às sextas-feiras; Um discurso edificante: a pecadora; Dois discursos para comunhão às sextas-feiras; Para auto-exame; Julguem vocês mesmos!; imutabilidade de Deus: um discurso; O Momento números I-X, Isto precisa ser dito, e que seja dito, O Juizo de Cristo sobre o cristianismo oficial, Os artigos do Kirkecamp no A Pátria.

d) as obras heteronímicas do segundo período, 5 obras, (18461850): O livro sobre Adler; A crise e uma crise na vida de uma atriz; Dois ensaios ético-religiosos; $O$ desespero humano; Prática do cristianismo.

e) as obras e fontes autopsicográficas, 11 obras, (1818-1855): Os diários e papéis de Kierkegaard; Cartas e documentos; Artigos em jornais; Os sermões de prova de Kierkegaard; As notas sobre as preleções de Schelling em Berlim; A dialética da comunicação ética e ético-religiosa; Resposta a Theophilos Nicolaus; Ponto de vista explicativo da minha obra como escritor; Sobre minha obra como autor; $O$ indivíduo singular; Neutralidade armada.

A produção literária de Kierkegaard foi organizada do princípio ao fim com o duplo caráter: estético e religioso. Esta duplicidade foi consciente e, segundo Kierkegaard, ela é condição dialética fundamental de toda a sua obra. ${ }^{52} \mathrm{O}$ religioso está presente desde o princípio e o estético está presente mesmo no último momento. ${ }^{53}$ Principiar com o estético significa lançar mão de uma apologética diferente da tradicional, procurando cativar os seus ouvintes a partir das categorias provisórias do seu estágio existencial ilusório onde não há a decisão que transforma o existente em indivíduo autêntico. Tendo isso em mente, a obra de

\footnotetext{
52 KIERKEGAARD, 1986, p. 27-8.

${ }^{53}$ Ibidem, p. 28.

192 • Universidade CATÓlica dePernambuco
} 
Kierkegaard é composta tendo uma intenção inegociável: demonstrar a seriedade do estágio religioso - esfera da existência autêntica.

Portanto, quando na cristandade um autor religioso, cujo pensamento total se resume no tornar-se cristão, quer chegar à possibilidade de tornar os homens atentos (porque o sucesso é outro assunto), deve começar por ser autor estético e conservar, até a um certo ponto, esta faculdade; mas tem de impor-se um limite, porque não usa este gênero de produção a não ser para despertar a atenção. E há uma coisa que não deve esquecer, a retenção da adição: deve distinguir o religioso, que é o decisivo, do estético, que é o incógnito, a fim de que o jogo dialético não seja pura tagarelice. $^{54}$

\section{Considerações Finais}

A partir da sua extensa obra, podemos perceber que a existência é o tema crucial da filosofia kierkegaardiana, que se desenvolve, através de escritos veronímicos e pseudonímicos, num movimento dialético cujo objetivo era despertar os seus contemporâneos para a seriedade do que significava viver. Quando nos aproximamos do pensamento filosófico de Kierkegaard notamos que a sua obra está diretamente voltada para a concretude da existência humana, com todas as suas possíveis implicações, problemas, possibilidades e limites.

A sua biografia está numa relação dialógica com a sua filosofia, ou seja, a vida de Kierkegaard talvez seja mais relevante para a sua obra do que aconteceu com a maioria dos grandes nomes da história da filosofia. Nesse particular, muitos eruditos que se dedicam a estudar suas ideias entendem ser necessário começar pela sua personalidade, embora o conteúdo filosófico dos seus livros subsista autonomamente. ${ }^{55}$ Outros advertem, entretanto, quanto ao perigo de se ler Kierkegaard muito mais psicanaliticamente do que filosoficamente; tomando a sua biografia

${ }_{55}^{54}$ KIERKEGAARD, 1986, p.47.

55 Cf. MACKINTOSH, Hugh. Corrientes Teológicas Contemporáneas: De Schleiermacher a Barth. Argentina: Methopress, 1964, p.200.. 
como referencial hermenêutico maior. ${ }^{56}$

Diante de tudo isso, podemos afirmar, sem dúvida, que a sua biografia fornece o pano-de-fundo não apenas vivencial, mas principalmente fundamental para a sua compreensão de mundo, sem que isso diminua ou restrinja o impacto e a relevância filosófica daquilo que ele escreveu. Portanto, o impacto de sua biografia sobre a sua obra não pode ser nem exagerada nem desprezada.

${ }^{56}$ Estudiosos como Howard Hong, têm alertado quanto a este erro, isto é, de se estudar a obra kierkegaardiana exclusivamente sob a influência interpretativa de uma "falácia genética". Cf. GOUVÊA, 2000, p.25.

194 • Universidade Católica de Pernambuco 